\title{
The prevention of dental caries and dental health of 12-year-old children in Żywiec District in Silesian Voivodeship - - a Polish experience
}

\author{
Profilaktyka próchnicy a stan uzębienia dzieci 12-letnich w powiecie żywieckim \\ w województwie śląskim - doświadczenia polskie \\ Urszula Kalińska, Magdalena Hartman-Petrycka (D), Barbara Błońska-Fajfrowska \\ Department of Basic Biomedical Science, School of Pharmacy with the Division of Laboratory Medicine in Sosnowiec, \\ Medical University of Silesia, Katowice, Poland
}

\begin{abstract}
INTRODUCTION: To counteract tooth decay in the Żywiec area, the local authorities implemented a health programme aimed at children from 4 to 15 years of age. The programme included educational and preventive actions (oral examinations and the sealing of I and II permanent molars). The aim of this study was to measure the effectiveness of the health programme.

MATERIAL AND METHODS: The 12-year-olds who participated in the study were from: the town of Żywiec and covered by the Programme (P group; $\mathrm{n}=441$ ); the town of Żywiec, but not covered by the Programme (CT group; $\mathrm{n}=131$ ) and non-participants in the Programme from the countryside around Żywiec (CR group; $\mathrm{n}=135)$. The effectiveness of the programme was measured by analysing a survey evaluating the children's awareness of oral health and an examination of their teeth, in particular, the first and second permanent molars.

RESULTS: The children from Group P were more knowledgeable $(\mathrm{p}<0.001)$, had a lower frequency of decay in their permanent teeth $(p<0.001)$, lower than average values for DMFT $(1.3 ; p<0.001)$ and DMFS $(1.4 ; p<0.001)$, lower rates of $\mathrm{SiC}(3.2 ; \mathrm{p}<0.001)$ and higher rates of preventive sealant on I $(\mathrm{p}<0.001)$ and II $(\mathrm{p}<0.001)$ molars, than in both control groups. For comparison, Group CT: DMFT $=4.5, \mathrm{DMFS}=5.2, \mathrm{SiC}=7.2$; and group CR: $\mathrm{DMFT}=3.5$, $\mathrm{DMFS}=4.3, \mathrm{SiC}=7.0$. The treatment index in Group CR (0.44) was much lower than in Groups P $(0.80)$ and CT $(0.76)$. CONCLUSIONS: Implementing a preventative programme of this nature could bring benefits not only in Poland but also in countries where the state of oral health is very low.
\end{abstract}

KEY WORDS

12-year-old children, health programme, frequency of caries, DMFT, sealing of molars

\section{STRESZCZENIE}

WSTĘP: Aby obniżyć częstość występowania próchnicy zębów w Żywcu, władze samorządowe wdrożyły program dedykowany dzieciom w wieku 4-15 lat. Program obejmował działania edukacyjne i profilaktyczne (badanie jamy ustnej oraz lakowanie I i II stałych zębów trzonowych). Celem pracy było zmierzenie skuteczności programu zdrowotnego.

\begin{tabular}{|c|c|c|c|}
\hline Received: 27.01.2019 & Revised: 27.02.2019 & Accepted: 02.06.2019 & Published online: 17.09 .2019 \\
\hline
\end{tabular}

Address for correspondence: Drn. med. Magdalena Hartman-Petrycka, Katedrai Zakład Podstawowych Nauk Biomedycznych, Wydział Farmaceutyczny z Oddziałem Medycyny Laboratoryjnej w Sosnowcu, Śląski Uniwersytet Medyczny w Katowicach, ul. Kasztanowa 3, 41-205 Sosnowiec, tel. + 4832 269 98 30, e-mail: mhartman@sum.edu.pl

Copyright $\odot$ Śląski Uniwersytet Medyczny w Katowicach

www.annales.sum.edu.pl 
MATERIA $~$ I METODY: W badaniu wzięli udział 12-letni uczniowie: z miasta Żywiec objęci programem profilaktycznym (grupa P; $\mathrm{n}=441$ ); z miasta Żywiec nieobjęci takim programem (grupa CT; $\mathrm{n}=131$ ) oraz ze wsi w powiecie żywieckim, również nieuczestniczący w programie (grupa CR; $\mathrm{n}=135$ ). Skuteczność programu była oceniana na podstawie wiedzy dzieci na temat zdrowia jamy ustnej oraz oceny stanu uzębienia, w szczególności pierwszych i drugich zębów trzonowych stałych.

WYNIKI: Dzieci z grupy P miały większą wiedzę $(\mathrm{p}<0,001)$, obserwowano u nich niższą częstotliwość próchnicy zębów stałych ( $\mathrm{p}<0,001)$, niższe średnie wartości DMFT $(1,3 ; \mathrm{p}<0,001)$ i DMFS $(1,4 ; \mathrm{p}<0,001)$, niższe wartości $\mathrm{SiC}(3,2 ; \mathrm{p}<0,001)$ oraz wyższe wskaźniki lakowania I $(\mathrm{p}<0,001)$ i II $(\mathrm{p}<0,001)$ zębów trzonowych niż w obu grupach kontrolnych. Dla porównania w grupie CT: DMFT $=4,5 ; \mathrm{DMFS}=5,2 ; \mathrm{SiC}=7,2, \mathrm{w}$ grupie CR: $\mathrm{DMFT}=3,5$; $\mathrm{DMFS}=4,3 ; \mathrm{SiC}=7,0$. Wskaźnik leczenia zębów w grupie $\mathrm{CR}(0,44)$ był znacznie niższy niż w grupach $\mathrm{P}(0,80)$ i CT $(0,76)$.

WNIOSKI: Realizacja programu profilaktycznego o takim charakterze mogłaby przynieść korzyści nie tylko w Polsce, lecz także w krajach, w których stan zdrowia jamy ustnej jest bardzo niekorzystny.

\section{SŁOWA KLUCZOWE}

dzieci 12-letnie, program zdrowotny, frekwencja próchnicy, DMFT, lakowanie zębów trzonowych

\section{INTRODUCTION}

Dental caries is the most common chronic disease in children. The prevalence of dental caries and periodontal disease depends on lifestyle and provisions in the health system $[1,2,3]$.

In Poland, the organisation of free dental care for children and adolescents up to 18 years old is paid for by the health care service [4]. However, this free dental care and prevention does not fully cover the recommendations of those Polish organisations which are responsible for dental care in the child population (Polish Dental Association, Polish Society of Pediatric Dentistry). Although primary school pupils (7-12 years old) have the possibility of benefiting from fluoride treatments administered by a nurse or school dental hygienist, access to free professional preventative dental care is patently limited. Since 2016, dental sealants of the sixth teeth have been available only once to children up to their eighth birthday (up until 2015 sealants were only available to children who had not yet reached their seventh birthday) [5]. The sealing of the seventh teeth is not refundable.

In view of the shortcomings of the countrywide system, some regions and municipalities are carrying out additional educational and preventive actions.

The main aim of this paper is to ascertain whether the educational and preventive measures carried out within the local government health programme are both adequate and effective.

\section{MATERIAL AND METHODS}

The local government programme 'The Prevention of Dental Caries in Children and Adolescents in the Żywiec Area' (the Programme) has been running since 1999. The observations come from research conducted in the years 2007-2015.

Educational and preventive activities have been carried out in nursery schools and elementary schools under the financial control of the Żywiec municipality and also in

\section{WSTĘP}

Choroba próchnicowa jest najczęstszą chorobą przewlekłą u dzieci. Częstość występowania próchnicy i chorób przyzębia zależy od stylu życia oraz rozwiązań w systemach ochrony zdrowia $[1,2,3]$.

W Polsce organizacja bezpłatnej opieki stomatologicznej (profilaktyki i leczenia) dla dzieci i młodzieży do lat 18 jest gwarantowana w świadczeniach opieki zdrowotnej finansowanych ze środków publicznych [4]. Proponowana przez ministra zdrowia opieka stomatologiczna dla dzieci, w tym profilaktyka, tylko częściowo pokrywa się z rekomendacjami polskich organizacji zajmujących się bezpośrednio tematyką stomatologiczną w populacji dzieci (Polskie Towarzystwo Stomatologiczne, Polskie Towarzystwo Stomatologii Dziecięcej). Chociaż uczniowie szkół podstawowych (7-12 lat) na terenie całego kraju mają możliwość korzystania z grupowej profilaktyki fluorowej, prowadzonej przez pielęgniarki lub higienistki szkolne, dostęp do bezpłatnej profesjonalnej profilaktyki stomatologicznej jest zdecydowanie ograniczony. Od 2016 r. lakowanie zębów szóstych przysługuje dzieciom tylko jeden raz, do ukończenia 8 roku życia (r.ż.; do 2015 r. z lakowania mogły korzystać dzieci do 7 r.ż.) [5]. Lakowanie zębów siódmych nie podlega refundacji.

Biorąc pod uwagę niedostatki systemu ogólnokrajowego, w niektórych regionach i gminach realizowane są dodatkowe działania edukacyjno-profilaktyczne w ramach programów samorządowych.

Głównym celem niniejszej pracy jest uzyskanie odpowiedzi na pytanie o efektywność i skuteczność działań edukacyjnych i profilaktycznych, prowadzonych w ramach samorządowego programu zdrowotnego.

\section{MATERIA I METODY}

Od 1999 r. do chwili obecnej w gminie Żywiec prowadzony jest program samorządowy pt.: „Zapobieganie próchnicy zębów u dzieci i młodzieży w gminie Żywiec" (Program). Obserwacje przedstawione w niniej- 
the Local Government Preventive Dental Practice for Children (the Practice) located in one of the largest primary schools in the area.

Free caries prevention (primary and secondary) is aimed at preschool children. A continuation programme is provided for pupils in the first, second and sixth grades of primary school. In addition it is extended to those in the third grade of middle school, if they have been going to the Practice and taking part in the oral health and hygiene programme (middle school students participated in the program until August 31, 2019).

Preschool establishments in Żywiec implement a basic programme promoting health education for oral health, including the implementation of proper hygiene and nutritional habits. In nursery school, children, from the age of four, brush their teeth with fluoride toothpaste at least once a day. In 5- and 6-year-old children, fivefold fluoridation of the teeth is carried out using a brush-on fluoride gel (previously a study on the concentration of fluoride in the Żywiec water supply, registered an amount of $<0.07 \mathrm{mg} / \mathrm{l}$, which is not a high level). In addition, children whose permanent molars have come through are invited to the Practice for coating (sealing) of tooth fissures.

The educational activity for early school children (7and 8-year-olds) is the continuation of visits to the Practice. Here they are given hygiene instructions, reminding them of correct brushing techniques and a series of talks on oral health.

Children in the higher grades of primary school also participate in oral health education. Professional, free dental prophylaxis among 11- and 12-year-old children provides:

- a dental examination and sealing of the second permanent molars,

- evaluation and possible supplementation of previously sealed first permanent molar teeth (the procedure of sealing the sixth teeth is usually undertaken in 6to 8-year-olds).

Up until 2005 tooth sealing was done by means of Helioseal and since 2005 Helioseal F (Ivoclar Vivadent AG).

The study of 12-year-old children, involved 707 pupils in the 6th grade of primary school, who were divided into 3 groups:

1) Prevention group $P-441$ children from the town of Żywiec, who began their participation in the Preventive Programme in nursery school;

2) Control group $C T-131$ children from the town of $\dot{Z} y-$ wiec who did not participate in the preventive dental treatment within the Programme; the reasons for these children not being included in the Programme were either because of parental apathy or lack of consent, or they were undertaking their own preventive treatment or the molars already had decay and/ /or were being or had been treated;

3) Control group CR - 135 children from rural areas around Żywiec, who did not participate in the Programme either. szej pracy pochodzą z badań prowadzonych w latach 2007-2015.

Działania edukacyjno-profilaktyczne prowadzone są na terenie przedszkoli i szkół, których organem prowadzącym jest gmina Żywiec, oraz w Samorządowym Gabinecie Profilaktyki Stomatologicznej dla Dzieci (Gabinet), który ma siedzibę w jednej z największych szkół podstawowych na terenie (miasta) Żywca.

Bezpłatna profilaktyka próchnicy (pierwotna i wtórna) skierowana jest do dzieci przedszkolnych, jednak jej kontynuację przewidziano u uczniów z klas pierwszych, drugich i szóstych szkół podstawowych, a także - biorąc pod uwagę wdrożone wcześniej nawyki higieniczne - u gimnazjalistów klas trzecich, jeśli ci ostatni zgłoszą się do Gabinetu (uczniowie szkół gimnazjalnych uczestniczyli w programie do 31 sierpnia 2019 r.).

W placówkach przedszkolnych w Żywcu realizowane są podstawy programowe dotyczące edukacji prozdrowotnej ukierunkowanej na zdrowie jamy ustnej, wdrażane są właściwe nawyki higieniczno-żywieniowe, a dzieci od 4 r.ż. przynajmniej raz dziennie po posiłku szczotkują zęby pastą z fluorem. W grupach dzieci 5i 6-letnich prowadzona jest 5-krotna grupowa fluoryzacja zębów metodą szczoteczkowania $\mathrm{z}$ zastosowaniem żelu fluorowego (wcześniej wykonano badanie dotyczące stężenia fluorków w wodzie z sieci wodociągu miejskiego Żywca, które nie wykazało podwyższonych wartości tych związków $<0,07 \mathrm{mg} / \mathrm{l})$. Dodatkowo dzieci z wyrżniętymi I zębami trzonowymi stałymi zapraszane są do Gabinetu na zabiegi lakowania (uszczelniania) bruzd zębowych.

Działania edukacyjne wśród dzieci wczesnoszkolnych (7- i 8-letnich) są kontynuacją wizyt adaptacyjnych w Gabinecie. Obejmują one instruktaże higieniczne, przypominające o właściwych technikach mycia zębów, oraz serię pogadanek na temat zdrowia jamy ustnej.

Dzieci ze starszych klas szkół podstawowych (11i 12-latki) również uczestniczą w edukacji związanej z promocją zdrowia jamy ustnej. Profesjonalna, bezpłatna profilaktyka stomatologiczna u tych dzieci przewiduje:

- przegląd jamy ustnej i lakowanie II zębów trzonowych stałych,

- ocenę i ewentualne uzupełnianie wcześniej zakładanego laku w I zębach trzonowych stałych (zabiegi lakowania zębów szóstych zwykle przeprowadzane są u dzieci 6-8-letnich).

Lakowanie zębów do 2005 r. prowadzono z użyciem światłoutwardzalnego białego laku Helioseal, a od 2005 r. jest to Helioseal F z zawartością fluoru (Ivoclar Vivadent AG).

W badaniu dzieci 12-letnich udział wzięło 707 uczniów klas szóstych, których podzielono na trzy grupy:

1) grupę profilaktyczną $\mathrm{P}-441$ dzieci z (miasta) Żywca, objętych Programem profilaktycznym od przedszkola;

2) grupę kontrolną CT - 131 dzieci z (miasta) Żywca, które nie korzystały z profilaktyki stomatologicznej w ramach realizowanego Programu; przyczynami braku włączenia do Programu były: zaniedbania ro- 
For those children not included in the Programme, oral health promotion was limited either to the school nurse giving basic information related to correct brushing with a fluoride preparation during school fluoridation or by teachers who organised lessons on oral health which were provided in the basic programmes.

The impact of the Programme on the 12-year-olds, pupils in the 6th grade of primary school, were assessed by a questionnaire measuring their knowledge and awareness of dental health procedures and an assessment of the condition of their teeth.

The survey question "What do you know about oral hygiene?" came from the "Your Beautiful Smile" health programme, which was developed by Wrigley in collaboration with the Polish Dental Association in 2000. The assessment of the knowledge of the 12-year-olds was based on the knowledge score obtained from a common analysis of all fourteen sentences in the survey.

The following dental indicators were used to assess the dental condition of the 12-year-old children:

1. Frequency of caries shown by the percentage of children with caries in permanent teeth, and in I and II permanent molars.

2. The severity of caries, showing the severity of the disease, using the indicators:

- the average number of DMFT (Decayed, Missing and Filled Teeth) including the components (DT, MT, FT) for permanent teeth,

- the average number of DMFT including its components for I and II permanent molar teeth (DMF 6 Teeth - DMF6T and DMF 7 Teeth - DMF7T),

- the average number of DMFS (Decayed, Missing and Filled Surfaces Teeth) with respect to the tooth surface affected by caries and its effects on all permanent teeth as well as I and II molars (DMFS 6 Teeth and DMFS 7 Teeth).

3. The relevant indicator of tooth decay - the $\mathrm{SiC}$ index - Significant Caries Index (according to Bratthall) [6]. This index was calculated for all permanent teeth $(\mathrm{SiC})$ and I and II permanent molar teeth (SiC 6 Teeth - SiC6 and SiC 7 Teeth - SiC7). For the purposes of the calculations, one third of the children with the most severe caries were considered.

4. Treatment index for permanent teeth and I permanent molars. This was calculated as the ratio of teeth filled to the total of teeth with caries plus teeth filled [7].

5. Prophylactic index for sealing I and II permanent molars, expressed as the percentage of children with sealed I and II molars (T6 and T7).

The Bioethics Committee of the Medical University of Silesia in Katowice approved the research project (Number KNW/02/KB1/169/11 from 25 October 2011). The parents or legal guardians of the children gave their consent to all the activities relating to the Programme. The Żywiec Council agreed that the data from the Practice documentation could be used in order to carry out the research (Letter BOB.036.3.1.2011 from 19 September 2011). dziców lub brak zgody na udział w programie, realizowanie profilaktyki we własnym zakresie, aktywna próchnica zębów trzonowych, zęby trzonowe w trakcie leczenia bądź wyleczone;

3) grupę kontrolną $C R-135$ dzieci z terenów wiejskich powiatu żywieckiego, również niebiorących udziału w Programie.

U dzieci nieobjętych Programem promocja zdrowia jamy ustnej była ograniczona do przekazania przez pielęgniarkę szkolną podstawowych informacji związanych z właściwym szczotkowaniem zębów preparatem fluorowym podczas szkolnej fluoryzacji zębów. Informacje mogli również przekazywać nauczyciele, którzy prowadzili z dziećmi zajęcia - ujęte w podstawach programowych - dotyczące obszaru edukacyjnego związanego ze zdrowiem.

Efekty i skuteczność Programu u 12-latków, uczniów szóstych klas szkół podstawowych, mierzono poprzez badanie ankietowe oceny wiedzy i świadomości prozdrowotnej oraz ocenę stanu uzębienia. Ankieta „Co wiesz o higienie jamy ustnej?” pochodziła z programu zdrowotnego „Twój Piękny Uśmiech”, który powstał dzięki firmie Wrigley przy współpracy Polskiego Towarzystwa Stomatologicznego w 2000 r. Oceny dokonano na podstawie wskaźnika wiedzy uzyskanego ze wspólnej analizy wszystkich czternastu zdań zawartych w ankiecie.

Do oceny stanu uzębienia dzieci 12-letnich zostały wykorzystane następujące wskaźniki stomatologiczne:

1. Frekwencja próchnicy, czyli częstość występowania choroby, przedstawiona odsetkiem dzieci z próchnicą w zębach stałych, a także w I i II zębach trzonowych stałych.

2. Intensywność próchnicy, wskazująca na ciężkość przebiegu choroby, z wykazaniem wskaźników:

- średnia liczba DMFT (zęby z próchnicą, usunięte, wypełnione) dla wszystkich zębów stałych z uwzględnieniem składowych (DT, MT, FT),

- średnia liczba DMFT dla I i II zębów trzonowych stałych (DMF 6 Teeth - DMF6T i DMF 7 Teeth DMF7T) z uwzględnieniem składowych,

- średnialiczbaDMFS, w odniesieniu do powierzchni zębów dotkniętych chorobą próchnicową i jej skutkami dla wszystkich zębów stałych oraz dla I i II zębów trzonowych (DMFS 6 Teeth i DMFS 7 Teeth).

3. Istotny wskaźnik próchnicy zębów - SiC index (wg Bratthalla) [6]. Wskaźnik ten obliczono dla wszystkich zębów stałych (SiC) oraz I i II zębów trzonowych stałych (SiC 6 Teeth - SiC6 i SiC 7 Teeth SiC7). Podczas obliczeń brano pod uwagę 1/3 dzieci z najbardziej nasiloną próchnicą.

4. Wskaźnik leczenia dla zębów stałych i I zębów trzonowych stałych. Obliczono go jako stosunek zębów wypełnionych do sumy zębów z próchnicą i wypełnionych [7].

5. Wskaźnik profilaktyczny dotyczacy lakowania I i II zębów trzonowych stałych, wyrażony poprzez określenie odsetka dzieci z zalakowanymi I i II zębami trzonowymi (T6 i T7). 
The statistical analysis was performed using STATISTICA 10.0 PL. Data on the interval scale was presented as averages with standard deviation, and in nominal and ordinal scales as percentages. Interval data was compared using the univariate analysis of variance. Sequential variables were compared using the chi-square test. Results $\mathrm{p}<0.05$ were assumed to be statistically significant.

\section{RESULTS}

Statistically significant lower rates of knowledge were found in the group of 12-year-olds who were not included in the preventive programme, both from the town (CT) and from the country areas (CR), compared to the 12-year-olds from Group P $(\mathrm{p}<0.001)$. Comparing the two control groups $\mathrm{CT}$ and $\mathrm{CR}$, the knowledge was significantly higher in the 12 -year-old CT group $(\mathrm{p}<0.05$; Fig. 1).

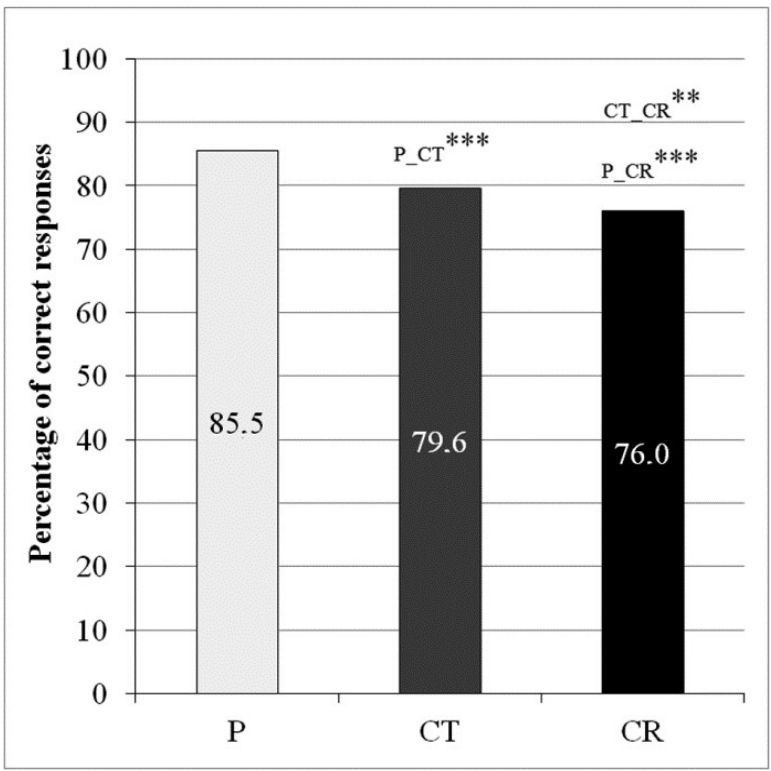

Fig. 1. Assessment of knowledge for $P, C T$ and CR groups; ${ }^{* * *} p<0.001$ ${ }^{* *} p<0.05$.

Ryc. 1. Ocena wiedzy w grupach P, CT i CR; ${ }^{* * *} p<0,001,{ }^{* *} p<0,05$

The incidence of caries in permanent teeth as well as in I and II permanent molars was statistically significantly lower in the P group than in the CT $(\mathrm{p}<0.001)$ and CR $(p<0.001)$ groups (Fig. 2). There was no statistically significant difference between the $\mathrm{CT}$ and $\mathrm{CR}$ groups. In Group P, statistically significantly lower mean DMFT and DMFS values were observed compared to the mean values for the CT $(p<0.001)$ and CR groups $(p<0.001$; Table I). There were no significant differences detected between the CT and CR groups. Certain elements (DT, FT and MT) of the mean DMFT values for permanent teeth were best seen in Group P.

In all the groups, the mean DMFT values (including DT, FT) as well as DMFS indices for permanent first molars were lower compared to the above mentioned values for the total permanent teeth (Table I). Group P
Komisja Bioetyczna Śląskiego Uniwersytetu Medycznego w Katowicach, Uchwałą Nr KNW/02/KB1/169/11 z dnia 25 października 2011 r., pozytywnie zaopiniowała projekt badań. Na wszystkie działania związane z Programem rodzice lub opiekunowie prawni dzieci wyrazili zgodę. Urząd Miejski w Żywcu pismem BOB.036.3.1.2011 z dnia 19 września 2011 r. wyraził zgodę na wykorzystanie danych z dokumentacji Gabinetu do realizacji niniejszej pracy.

Analiza statystyczna została przeprowadzona z użyciem programu STATISTICA 10.0 PL (StatSoft Polska, Kraków). Dane w skali interwałowej przedstawiono jako średnie wraz z odchyleniem standardowym, a w skali nominalnejiporządkowejjakoudziały procentowe. Dane $\mathrm{w}$ skali interwałowej porównano $\mathrm{z}$ wykorzystaniem jednoczynnikowej analizy wariancji. Zmienne w skali porządkowej porównywano testem $\mathrm{Chi}^{2}$. Za istotne statystycznie przyjęto wyniki, dla których $\mathrm{p}<0,05$.

\section{WYNIKI}

Wykazano statystycznie istotnie niższe wartości wskaźnika wiedzy w grupach 12-latków nieobjętych programem profilaktycznym, zarówno z miasta (CT), jak i ze wsi (CR), w porównaniu ze wskaźnikiem uzyskanym u 12-latków z grupy $\mathrm{P}(\mathrm{p}<0,001)$. Porównując grupy kontrolne CT i CR, wskaźnik wiedzy był istotnie wyższy u 12-latków z grupy CT ( $<<0,05$; ryc. 1$)$.

Częstość występowania próchnicy $\mathrm{w}$ zębach stałych, a także w I oraz II zębach trzonowych stałych, była istotnie statystycznie niższa $\mathrm{w}$ grupie $\mathrm{P}$ niż $\mathrm{w}$ grupach CT ( $<<0,001)$ i CR ( $<0,001$; ryc. 2$)$. Nie wykazano natomiast statystycznie istotnej różnicy między grupami CT i CR.

$\mathrm{W}$ grupie $\mathrm{P}$ stwierdzono statystycznie istotnie niższe wartości średnich liczb DMFT i DMFS względem takich średnich grup CT $(p<0,001)$ i CR $(p<0,001$; tab. I). Nie stwierdzono istotnych różnic między grupą CT i CR. Poszczególne składowe (DT, FT i MT) średniej liczby DMFT dla zębów stałych najkorzystniej przedstawiały się w grupie P.

We wszystkich grupach wartości średniej liczby DMFT (wraz ze składowymi DT i FT), a także wskaźnika DMFS dla I zębów trzonowych stałych były niższe w porównaniu z wartościami tych wskaźników dla zębów stałych ogółem (tab. I). W grupie P stwierdzono statystycznie istotnie niższe wartości średnich liczb DMFT i DMFS dla I zębów trzonowych stałych względem grup CT $(p<0,001)$ i CR $(p<0,001)$. Zaobserwowano także statystycznie istotnie niższe wartości tych wskaźników w grupie CR względem grupy CT (odpowiednio DMF 6 Teeth: $\mathrm{p}<0,01$ i DMFS 6 Teeth: $\mathrm{p}<0,05)$.

Najniższe wartości średniej DMFT dla II zębów trzonowych stałych zaobserwowano w grupie P $(0,2$; tab. I). Wartości wskaźnika DMFS dla II zębów trzonowych u 12-latków z grup P i CR były takie same jak dla średniej liczby DMFT, a w grupie CT nieznacznie większe. $\mathrm{W}$ grupie $\mathrm{P}$ stwierdzono statystycznie istotnie niższe wartości średnich liczb DMFT i DMFS dla II zębów 


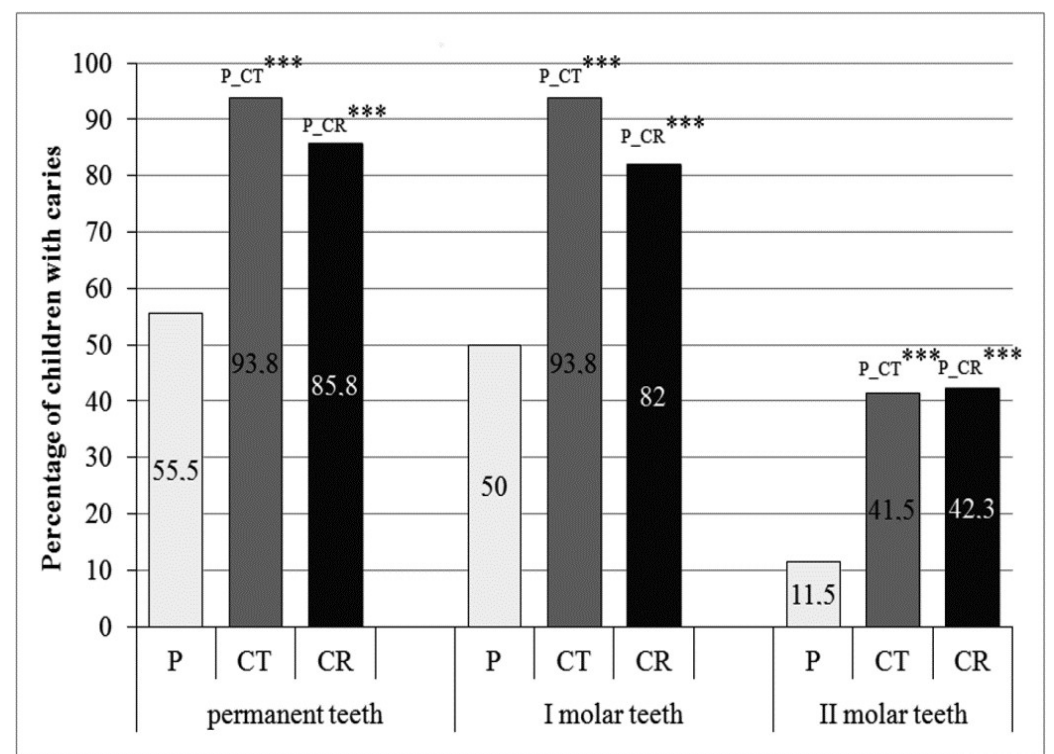

Fig. 2. Incidence of caries in permanent teeth and in I and II permanent molars for $P, C T$ and $C R$ groups; ${ }^{* * *} p<0.001$. Ryc. 2. Częstość występowania próchnicy w zębach stałych oraz w I i ll zębach trzonowych stałych w grupach P, CT i CR; *** $p<0,001$.

had statistically significantly lower mean DMFT and DMFS values for permanent first molars compared with the CT group $(\mathrm{p}<0.001)$ and the CR group $(\mathrm{p}<0.001)$. There were also statistically significantly lower values of the above indices in the CR group relative to the CT group (DMFT 6 Teeth: $\mathrm{p}<0.01$ and DMFS 6 Teeth: $\mathrm{p}<0.05)$.

The lowest mean DMFT values for permanent second molars were observed in Group P (0.2; Table I). The DMFS values for permanent second molar teeth in the 12-year-olds from Groups P and CR were the same as for the mean DMFT value. In the CT group it was slightly higher. Group P had significantly statistically lower mean DMFT and DMFS values for permanent second molars compared to the CT group $(\mathrm{p}<0.001)$ and the CR group $(\mathrm{p}<0.001)$. There was no significant difference between the CT and CR groups for the DMFT and DMFS values for second molars.

Group P had significantly lower values for SiC for permanent teeth and permanent I and II molars than for Groups CT $(\mathrm{p}<0.001)$ and CR $(\mathrm{p}<0.001)$. Statistically, there were no significant differences between the CT and $\mathrm{CR}$ groups.

There were statistically significantly higher rates of treatment in permanent teeth in Groups $\mathrm{P}$ and CT compared to Group CR ( $<<0.001)$, whereas Groups P and CT did not differ significantly (Table I). The statistical correlations between the groups for treated first molars and total treated teeth were similar.

The fewest children with sealed permanent first molars were recorded in the CT group (Table II). The percentage of children with sealed permanent first molars in Group P differed statistically significantly from those in the CT and CR groups $(\mathrm{p}<0.001)$. Parallel differences were observed between the groups for the second permanent molars $(\mathrm{p}<0.001)$. trzonowych stałych względem grup CT ( $<<0,001)$ i CR $(\mathrm{p}<0,001)$. Między grupami CT i CR nie stwierdzono istotnych różnic dla wskaźników DMFT i DMFS dla II zębów trzonowych.

Grupa P miała istotnie niższe wartości wskaźników SiC i SiC6 niż grupy CT i CR ( p < 0,001). Nie stwierdzono statystycznie istotnych różnic między grupami CT i CR.

Wykazano statystycznie istotnie wyższe wartości wskaźnika leczenia zębów stałych w grupach P i CT względem grupy $\mathrm{CR}(\mathrm{p}<0,001)$, natomiast grupy $\mathrm{P}$ i CT nie różniły się istotnie (tab. I). Zależności statystyczne między grupami w przypadku wskaźnika leczenia dla I zębów trzonowych były analogiczne do wskaźnika leczenia zębów stałych ogółem.

Najmniej dzieci z zalakowanymi zębami trzonowymi stałymi było w grupie CT (tab. II). Odsetek dzieci z zalakowanymi I zębami trzonowymi stałymi $\mathrm{w}$ grupie $\mathrm{P}$ różnił się $\mathrm{W}$ sposób statystycznie istotny od takich wartości w grupach CT i CR $(\mathrm{p}<0,001)$. Analogiczne różnice międzygrupowe zaobserwowano $\mathrm{w}$ przypadku II zębów trzonowych stałych $(\mathrm{p}<0,001)$.

\section{DYSKUSJA}

Na podstawie badania ankietowego dzieci 12-letnich wykazano, że działania edukacyjne prowadzone w ramach Programu były skuteczne i przełożyły się na przyrost wiedzy z zakresu zdrowia jamy ustnej. Przypuszczalnie był to jeden z czynników wpływających na lepsze parametry wskaźników zębowych uzyskanych $\mathrm{w}$ grupie $\mathrm{P} \mathrm{w}$ porównaniu $\mathrm{z}$ grupami CT i CR. Wyniki ogólnopolskiego badania monitoringowego wskazywały, że w 2014 r. odsetek 12-letnich dzieci wolnych od próchnicy wynosił 24,09, a intensywność 
Table I. Program effectiveness measures in permanent teeth (T), as well as in 1st and 2nd permanent molars (T6 and T7), in groups P, CT and CR Tabela I. Mierniki efektywności Programu w zębach stałych (T), a także w I i ll zębach trzonowych stałych (T6 i T7) w grupach P, CT i CR

\begin{tabular}{|c|c|c|c|c|c|c|c|c|c|c|}
\hline \multirow{3}{*}{$\begin{array}{l}\text { Measure } \\
\text { of effectiveness } \\
\text { of Programme }\end{array}$} & \multirow{3}{*}{$\begin{array}{r}\text { Scope } \\
\text { permanent teeth }(T)\end{array}$} & \multicolumn{3}{|c|}{ Group P } & \multicolumn{3}{|c|}{ Group CT } & \multicolumn{3}{|c|}{ Group CR } \\
\hline & & \multirow{2}{*}{$\frac{\mathbf{x}}{1.3}$} & \multicolumn{2}{|c|}{ $\pm 95 \% \mathrm{Cl}$} & \multirow{2}{*}{$\frac{\mathbf{x}}{4.5}$} & \multicolumn{2}{|c|}{ $\pm 95 \% \mathrm{Cl}$} & \multirow{2}{*}{$\begin{array}{c}\mathbf{x} \\
3.5\end{array}$} & \multicolumn{2}{|c|}{ $\pm 95 \% \mathrm{Cl}$} \\
\hline & & & 1.2 & 1.5 & & 4.0 & 4.9 & & 3.0 & 4.1 \\
\hline \multirow[t]{3}{*}{ DMFT } & 1st molars (T6) & 0.9 & 0.8 & 1.0 & 3.1 & 2.9 & 3.3 & 2.2 & 2.0 & 2.5 \\
\hline & 2nd molars (T7) & 0.2 & 0.1 & 0.2 & 0.7 & 0.5 & 0.9 & 0.8 & 0.6 & 1.0 \\
\hline & permanent teeth $(T)$ & 0.28 & 0.21 & 0.35 & 1.15 & 0.84 & 1.46 & 1.76 & 1.38 & 2.15 \\
\hline \multirow[t]{3}{*}{ DT } & 1st molars (T6) & 0.12 & 0.08 & 0.16 & 0.53 & 0.37 & 0.70 & 0.88 & 0.69 & 1.07 \\
\hline & 2nd molars (T7) & 0.08 & 0.04 & 0.11 & 0.36 & 0.20 & 0.51 & 0.55 & 0.38 & 0.73 \\
\hline & permanent teeth $(\mathrm{T})$ & 0.01 & 0.00 & 0.02 & 0.15 & 0.06 & 0.23 & 0.16 & 0.08 & 0.25 \\
\hline \multirow[t]{3}{*}{ MT } & 1st molars (T6) & 0.01 & 0.00 & 0.02 & 0.13 & 0.06 & 0.20 & 0.16 & 0.08 & 0.24 \\
\hline & 2nd molars (T7) & 0.00 & 0.00 & 0.00 & 0.00 & 0.00 & 0.00 & 0.00 & 0.00 & 0.00 \\
\hline & permanent teeth $(T)$ & 1.03 & 0.89 & 1.16 & 3.18 & 2.81 & 3.54 & 1.59 & 1.24 & 1.95 \\
\hline \multirow[t]{3}{*}{ FT } & 1st molars (T6) & 0.78 & 0.69 & 0.88 & 2.44 & 2.20 & 2.67 & 1.20 & 0.95 & 1.45 \\
\hline & 2nd molars (T7) & 0.08 & 0.04 & 0.11 & 0.06 & 0.20 & 0.51 & 0.24 & 0.09 & 0.38 \\
\hline & permanent teeth $(T)$ & 1.4 & 1.2 & 1.5 & 5.2 & 4.6 & 5.9 & 4.3 & 3.5 & 5.1 \\
\hline \multirow[t]{3}{*}{ DMFS } & 1st molars (T6) & 1.0 & 0.9 & 1.1 & 3.7 & 3.4 & 4.1 & 2.9 & 2.5 & 3.4 \\
\hline & 2nd molars (T7) & 0.2 & 0.1 & 0.2 & 0.8 & 0.5 & 1.0 & 0.8 & 0.6 & 1.0 \\
\hline & permanent teeth $(\mathrm{T})$ & 3.2 & 3.0 & 3.5 & 7.2 & 6.6 & 7.8 & 7.0 & 6.1 & 7.8 \\
\hline \multirow[t]{2}{*}{$\mathrm{SiC}$} & 1st molars (T6) & 2.2 & 2.1 & 2.4 & 4.0 & 4.0 & 4.0 & 3.8 & 3.7 & 4.0 \\
\hline & 2nd molars (T7) & 0.5 & 0.3 & 0.6 & 1.9 & 1.5 & 2.3 & 2.1 & 1.7 & 2.4 \\
\hline \multirow{2}{*}{ Treatment index } & permanent teeth $(T)$ & 0.80 & 0.75 & 0.84 & 0.76 & 0.71 & 0.82 & 0.44 & 0.36 & 0.52 \\
\hline & 1st molars (T6) & 0.86 & 0.82 & 0.90 & 0.82 & 0.76 & 0.87 & 0.51 & 0.42 & 0.59 \\
\hline
\end{tabular}

DMFT - average number of permanent teeth affected by active primary or secondary caries (D), teeth removed because of caries (M) and filled (F); DT, MT, FT - elements of average number of DMFT; $T$ - permanent teeth; T6 - permanent first molar; $T 7$ - permanent second molar; DMF6T - average number of permanent first molars (tooth 6 ) affected by caries, or removed or filled due to caries; DMF7T - average number of permanent second molars (tooth 7) affected by caries, or removed or filled due to caries; DMFS - average number of tooth surfaces affected by caries and their effects; indicator of intensity of decay on tooth surfaces; SiC index - Significant Caries Index (according to Bratthall); SiC6 - Significant Caries Index of first molar; SiC7 - Significant Caries Index of second molar; $x \pm 95 \% \mathrm{Cl}$ - mean \pm confidence interval.

DMFT - średnia liczba zębów stałych dotkniętych aktywną próchnicą pierwotną lub wtórna (D), zębów usuniętych z powodu próchnicy (M) oraz wypełnionych (F); DT, MT, FT - składowe średniej liczby DMFT; T - ząb stały; T6 - I ząb trzonowy stały; ząb szósty; T7 - II ząb trzonowy stały; zab siódmy; DMF6T średnia liczba I zębów trzonowych stałych (szóstych) dotkniętych próchnica, usuniętych i wypełnionych z powodu próchnicy; DMF7T - średnia liczba II zębów trzonowych stałych (siódmych) dotkniętych próchnica, usuniętych i wypełnionych z powodu próchnicy; DMFS - średnia liczba powierzchni zębów stałych dotkniętych próchnicą i jej skutkami; wskaźnik powierzchniowy intensywności próchnicy zębów stałych; SiC index - istotny wskaźnik próchnicy zębów (wg Bratthalla); SiC6 - istotny wskaźnik próchnicy I zębów trzonowych stałych; SiC7 - istotny wskaźnik próchnicy II zębów trzonowych stałych; $\mathrm{x} \pm 95 \% \mathrm{Cl}$ średnia \pm przedział ufności.

Table. II. Sealant indicators for Groups P, CT and CR Tabela II. Wskaźnik lakowania zebów w grupach P, CT i CR

\begin{tabular}{|c|c|c|c|c|}
\hline Sealant indicators & Scope & Group P & Group CT & Group CR \\
\hline \multirow{2}{*}{ Percentage of children with sealant on 1st molars (T6) } & at least one tooth & 96.8 & 16.0 & 28.8 \\
\hline & all four teeth & 43.3 & 0.8 & 3.7 \\
\hline \multirow{2}{*}{ Percentage of children with sealant on $2 \mathrm{nd}$ molars $(\mathrm{T} 7)^{*}$} & at least one tooth & 92.2 & 1.9 & 5.5 \\
\hline & all current teeth & 69.0 & 0.0 & 1.8 \\
\hline
\end{tabular}

* Out of $100 \%$ of children who already have their 2 nd molar.

* Za 100\% przyjęto liczbę dzieci, które miały wyrżnięte zęby siódme. 


\section{DISCUSSION}

Based on this survey, it has been shown that the educational activities carried out within the Programme were effective and resulted in an increase in oral health knowledge. This was one of the factors influencing the improved parameters of the dental indicators obtained in the P group compared to the CT and CR groups. The results of a nationwide monitoring study reported that in 2014 the percentage of 12-year-old children free from caries was 24.09, and the frequency of caries expressed by the average DMFT value reached 2.81 [8]. In the control groups, $\mathrm{CR}$ and $\mathrm{CT}$, the percentage of children without caries was lower than in the nationwide survey and was 14.2 and 6.2, respectively, while the DMFT value was higher with CR 3.5 and CT 4.5. Against this background the percentage of children without caries for Group P was 44.5 and the mean DMFT was 1.3. It is worth emphasising that the DMFS surface area index for Group P was comparable to DMFT and it was 1.4 , which means that decay was usually limited to one tooth surface. Unfortunately, in the CT and CR groups, the frequency of surface caries DMFS (CT 5.2 and CR 4.3) was decidedly higher than the DMFT in these groups (CT 4.5 and CR 3.5). This indicates that carious lesions in children from both control groups occurred on several dental surfaces.

The incidence of caries and DMFT values for Group P are similar to those results from other studies in Poland. In the Łódź Voivodeship, children from the preventive group who had undergone sealing of the sixth tooth registered $62.1 \%$ and 1.45 and in Poznan $60.67 \%$ and $1.59[9,10]$. Similar results in other European countries include: German 12-year-olds (50\% and 1.0) and, in a German preventive group from the city of Dortmund, where children were given a sealant on their sixth and seventh teeth (57.25\% and 1.62) [11].

Similarly, a high incidence of dental caries for children in the CT group, but with a lower DMFT, were found in Poland: Składnik-Jankowska and Kaczmarek [12] in a town in Lower Silesia (84.3\% and 3.71) and Rojek et al. [13] in the town of Lobez in West Pomerania (80\% and 2.73). A higher prevalence of tooth decay than in the CT group was noted in the Poznań Positive Control Group (97.87\% and 5.02) [14]. A lower incidence of caries and mean DMFT values as in the group of 12-year-olds from the CR group was found by Nuca et al. [15] in 12-year-olds in Romania (77.2\% and 3.31).

In Poland, a lower frequency and severity of dental caries (DMFT) was found by Perkowska et al. [9] in the Łódź Voivodeship (83.30\% and 2.2), and a higher frequency by Składnik-Jankowska and Kaczmarek [12] in a rural area in Lower Silesia $(96.9 \%$ and 5.25), and Rojek et al. [13] in the rural areas of Łobez in West Pomerania (93.4\% and 4.35).

The treatment rate for permanent teeth both in the prevention group (0.80) and in the control group (0.76) was higher than in 12-year-olds in a Polish monitoring study in 2014 (0.6) [8]. Unfortunately, the number of próchnicy wyrażona średnią liczbą DMFT osiągnęła wartość 2,81 [8]. W grupach kontrolnych CR i CT odsetek dzieci wolnych od próchnicy był niższy niż w badaniu ogólnopolskim i wynosił odpowiednio 14,2 i 6,2, natomiast wartość DMFT była wyższa - w CR 3,5 i CT 4,5. Grupa uczestnicząca w Programie profilaktycznym (P) na tym tle wypadła bardzo korzystnie. Odsetek dzieci wolnych od próchnicy wynosił 44,5, a średnia liczba DMFT - 1,3. Warto podkreślić, że wskaźnik powierzchniowy DMFS w grupie P był porównywalny z DMFT i wynosił 1,4, co oznacza, że ubytki próchnicowe ograniczone były najczęściej do jednej powierzchni zębowej. Niestety w grupach CT i CR intensywność próchnicy powierzchni zębowych DMFS (odpowiednio: CT 5,2 i CR 4,3) była zdecydowanie wyższa od liczby DMFT (CT 4,5 i CR 3,5). Wskazuje to, że ubytki próchnicowe u dzieci z obu grup kontrolnych występowały na kilku powierzchniach zębowych.

Porównując wyniki badań dzieci 12-letnich w niniejszej pracy z innymi danymi, można zaobserwować, że podobna jak w grupie P częstość występowania próchnicy oraz liczba DMFT występuje w Polsce w woj. łódzkim u dzieci z grupy profilaktycznej, które zostały poddane lakowaniu zębów szóstych $(62,1 \%$ i 1,45$)$, oraz w Poznaniu $(60,67 \%$ i 1,59$)[9,10]$. Podobne wyniki w innych krajach europejskich odnotowano u 12-latków z grupy profilaktycznej IP5 z Dortmundu, których w latach 1997-2007 poddano lakowaniu bruzd zębów szóstych i siódmych $(57,25 \%$ i 1,62) [11].

Podobnie wysoką częstość występowania próchnicy dla zębów stałych jak u dzieci w grupie kontrolnej CT, jednak o niższej liczbie DMFT, stwierdzili w Polsce Składnik-Jankowska i Kaczmarek [12] w małym mieście w woj. dolnośląskim $(84,3 \%$ i 3,71) oraz Rojek i wsp. [13] w mieście Łobez w woj. zachodniopomorskim $(80 \%$ i 2,73$)$. Wyższą intensywność choroby niż $\mathrm{w}$ grupie CT odnotowano w poznańskiej grupie pozytywnie kontrolnej $(97,87 \%$ i 5,02) [14]. Podobną częstość występowania próchnicy oraz średnią liczbę DMFT jak w grupie 12-latków z grupy CR stwierdzili Nuca i wsp. [15] u 12-latków w Rumunii (77,2\% i 3,31).

W Polsce niższą częstość i intensywność próchnicy (DMFT) uzyskali Perkowska i wsp. [9] w woj. łódzkim $(83,30 \%$ i 2,2$)$, natomiast wyższą Składnik-Jankowska i Kaczmarek [12] w środowisku wiejskim w woj. dolnośląskim $(96,9 \%$ i 5,25) oraz Rojek i wsp. [13] na obszarach wiejskich okolic miasta Łobez w woj. zachodniopomorskim $(93,4 \%$ i 4,35).

Zadowalające jest, że wskaźnik leczenia dla zębów stałych u 12-latków zarówno z grupy $\mathrm{P}(0,80)$, jak i CT $(0,76)$ był wyższy niż u 12-latków w polskim badaniu monitoringowym w 2014 r. $(0,6)$ [8]. Niestety 12-latki ze wsi (CR) miały 2-krotnie mniej wyleczonych zębów niż ich rówieśnicy z miasta $(0,44)$. Dzieci z grupy CT z Żywca nie zostały zakwalifikowane do Programu, a tym samym do lakowania zębów, m.in. ze względu na stwierdzoną próchnicę zębów trzonowych. Niemniej jednak zgłaszały się do samorządowego gabinetu profilaktyki stomatologicznej, ponieważ prowadzono w nim 
treated teeth in the 12-year-olds from the countryside (CR) was two times less than the treated teeth in their urban counterparts $(0.44)$. The children from the town of Żywiec in the control group (CT) did not qualify for the Programme. One of the reasons for this was because of the caries which were identified in their molars. However, they still came to the Practice because of the free dental check-ups. It was quite important that during the visits in the Practice, parents were given information about the state of their children's teeth because in the majority of cases, at a subsequent check-up, the children's teeth problems were found to have cleared up. Children and parents from the Żywiec countryside did not receive information on the current state of their child's teeth nor guidelines on prevention, which could have had a negative impact on the low rate of treatment in the CR group.

The $\mathrm{SiC}$ index value for permanent teeth in Group $\mathrm{P}$ was 3.2. This confirms that this group met the expectations included in the National Health Program 2007-2015 , which assumed a reduction in the $\mathrm{SiC}$ rate to a value of 4 as well as the assumptions made by the WHO that by 2015 there would be a significant reduction to 3 in the incidence of caries in European 12-year-olds $[16,17]$. The $\mathrm{SiC}$ index for permanent teeth in both the CT and CR groups was high (7.2 and 7.0, respectively) and was similar to the values for $\mathrm{SiC}$ from the nationwide survey in 2012 (7.4) [18]. This is alarming, and all the more so, given that the WHO's assumptions for the $\mathrm{SiC}$ value for European countries were already reached in 2010 in 12-year-olds in Germany $(2009-2.2)$, Sweden $(2008-2.5)$, and Finland $(2009-1.3)$ [19]. The $\mathrm{SiC}$ index for first molars in both control groups (CT 4.0 and CR 3.8) is very concerning. A $\mathrm{SiC}$ value of 4 suggests that at least one third of the children in both control groups had problems with all their permanent first molar teeth. In addition, the DT and FT values of the median number of DMFT for the first molars (sixth) in the CT and CR groups ( 0.53 and 2.44 and 0.88 and 1.20) showed that the situation was particularly worrying among the 12-year-olds from the countryside. To add to this bad news, the condition of the sixth teeth in both control groups using the MT values was 0.13 in the CT group and 0.16 in the CR group, which meant that in these groups, because of caries in the sixth teeth, there was a corresponding average loss of the sixth teeth of $1.3 \%$ and $1.6 \%$ out of the total number of teeth. In comparison, in the prophylactic group, the MT value for the sixth teeth was only 0.01 . The effectiveness of the Programme was particularly evident when assessing the condition of the second molar teeth (seventh). The incidence of caries and the DMFT values for the 7 th teeth in the prevention group $(\mathrm{P})$ were $11.55 \%$ and 0.2 respectively. In the children in the control groups CT and CR, the incidence of caries and the mean DMFT for the second molar teeth was almost four times higher than that found in Group P (CT 46.55\% and 0.7 and CR $42.35 \%$ and 0.8 ). bezpłatne kontrolne przeglądy jamy ustnej. Przekazywanie podczas wizyt w Gabinecie informacji o stanie uzębienia było dość istotne dla rodziców, ponieważ większość dzieci, u których wcześniej stwierdzono zęby chore, w trakcie kolejnego, kontrolnego badania miała wyleczone zęby, o czym informuje wskaźnik leczenia oraz średnia liczba FT. Dzieci i rodzice ze wsi w powiecie żywieckim nie otrzymywali informacji dotyczących aktualnego stanu uzębienia dzieci oraz wskazówek profilaktyczno-leczniczych, co mogło mieć wpływ na niski wskaźnik leczenia w grupie CR.

Wartość wskaźnika $\mathrm{SiC}$ dla zębów stałych w grupie $\mathrm{P}$ wynosiła 3,2. Potwierdza to zrealizowanie w tej grupie oczekiwań ujętych w Narodowym Programie Zdrowia na lata 2007-2015, który zakładał obniżenie wskaźnika SiC do wartości 4, oraz założeń WHO, przewidujących obniżenie istotnego wskaźnika próchnicy w grupie 12-latków w Europie do wartości 3 do 2015 r. [16,17]. Wskaźnik SiC dla zębów stałych w grupach CT i CR był wysoki (odpowiednio 7,2 i 7,0) i osiągnął zbliżone wartości do $\mathrm{SiC}$ z badania ogólnopolskiego z 2012 r. $(7,4)[18]$. Utrzymujący się przez wiele lat tak wysoki wskaźnik SiC w populacji polskich 12-latków, który jednocześnie nie wykazuje tendencji do obniżenia [8], budzi zaniepokojenie, tym bardziej że założenia WHO w odniesieniu do wartości wskaźnika SiC dla krajów europejskich zostały spełnione już przed 2010 r. w grupach dzieci 12-letnich w Niemczech (2009 - 2,2), Szwecji (2008 - 2,5) i Finlandii (2009 - 1,3) [19]. Niepokojąca była wartość $\mathrm{SiC}$ dla I zębów trzonowych w obu grupach kontrolnych (CT 4,0; CR 3,8). Wartość 4,0 sugerowała, że przynajmniej $1 / 3$ dzieci w tych grupach miała chore wszystkie pierwsze zęby trzonowe stałe. Dodatkowo wartości składowych DT oraz FT średniej liczby DMFT dla I zębów trzonowych (szóstych) w grupach CT i CR $(0,53$ i 2,44 oraz 0,88 i 1,20$)$ dowodziły, że sytuacja była niepokojąca zwłaszcza w grupie 12-latków ze wsi. Niezadowalająca była również liczba MT, która w grupie CT wyniosła 0,13, a w CR 0,16. $\mathrm{W}$ grupach CT i CR z powodu próchnicy nastąpiła więc utrata (odpowiednio) średnio 1,3\% i 1,6\% zębów szóstych z ogólnej liczby tych zębów. Dla porównania w grupie profilaktycznej liczba MT dla zębów szóstych wyniosła zaledwie 0,01. Skuteczność Programu była szczególnie widoczna podczas oceny stanu II zębów trzonowych stałych (siódmych). Częstość występowania próchnicy i liczba DMFT dla zębów siódmych w grupie $\mathrm{P}$ wyniosły odpowiednio $11,55 \%$ i 0,2 . U dzieci z grup kontrolnych CT i CR, nieobjętych lakowaniem I i II zębów trzonowych, frekwencja próchnicy i średnia liczba DMFT II zębów trzonowych osiągnęła niemal 4-krotnie wyższe wartości od tej, którą stwierdzono w grupie P (CT 46,55\% i 0,7; CR 42,35\% i 0,8). Lakowanie bruzd zębów lakami szczelinowymi istotnie przyczynia się do zmniejszenia próchnicy i jest zalecanym zabiegiem profilaktycznym u dzieci [20,21]. Analizując wyniki stanu uzębienia w grupie P można potwierdzić taką tezę, ponieważ dzieci z grupy profi- 
Sealing tooth fissures significantly contributes to the reduction of caries and is a recommended prophylactic treatment for children [20,21]. The condition of the teeth in Group P can confirm this thesis, because children from the Żywiec preventive group who underwent dental sealing had significantly better dental health than their peers from the control groups.

The results of a nationwide monitoring study in 2012 reported that the percentage of 12-year-old children with dental sealing in Poland was 32.9, in urban areas 36.2 , and in rural areas 28.6 [18]. However, in the national assessment, very large differences were found among voivodeships (the percentage ranged from 1.4 to 56.0). In the CT and CR groups, the percentage of children who have had at least one sixth tooth sealed was 16.03 and 28.75 , respectively, with sealant on the seventh tooth: 1.92 and 5.46. A totally different picture emerged in the Group P. The percentage of children with at least one sealed sixth tooth was 96.83 and the seventh was 92.17 , with all four of the sixth teeth sealed in $43.31 \%$ of children. The $3.17 \%$ of children with unsealed sixth teeth and $7.83 \%$ with unsealed seventh teeth in this group can be explained by the fact that they did not visit the dentist in the prevention clinic prior to the study.

Bearing in mind the reports in Polish and foreign literature which prove and confirm the positive effect of preventive sealant on the health of the teeth, we should look at the results of: Wędrychowicz-Welman and Stopa [14] - during a 3-year preventive programme including tooth sealing, the rate of tooth decay in a group of 11-12-year-olds was reduced; Hilt [22] - after a 5-year study of tooth sealants found $54.1 \%$ of sealed first molar teeth was preserved; Vrbic [23] - who after sealing up to $95.8 \%$ of the teeth surfaces, found, three years later, that the teeth were still completely sealed; Schulte et al. [24] - thanks to tooth sealant there was a reduction in the intensity of caries in groups of 12-year-old children from Heidelberg and Montpellier; Siudmak [11] - 12-year-olds from Dortmund, who did not have tooth sealant applied had a threefold greater chance of caries than their counterparts in the prevention group.

\section{CONCLUSIONS}

The indices of the frequency and intensity of caries in 12-year-olds indicated the high level of effectiveness of the Preventive Programme. In the 12-year-olds from the rural areas there were higher preventive and remedial needs for permanent teeth than for their urban peers. National preventive and remedial programmes in Poland are insufficient to ensure good oral health. It would be beneficial for Poles to have a national dental prevention programme that would provide all children with health education, tangible access to dental services from an early age, guaranteed tooth sealing of the sixth teeth after the age of 8 and guaranteed preventive sealing of the seventh teeth up to the age of 13 years. These educational and preventive actions introduced in the Programme could also benefit those countries where laktycznej z Żywca, poddane zabiegom uszczelniania lakiem I i II zębów trzonowych stałych, miały zęby w zdecydowanie lepszym stanie niż ich rówieśnicy z grup kontrolnych.

Wyniki ogólnopolskiego badania monitoringowego z 2012 r. informują, że odsetek dzieci 12-letnich, które miały uszczelnione lakiem zęby trzonowe, w Polsce wynosił 32,9, w mieście 36,2, a na wsi 28,6 [18]. W ocenie ogólnopolskiej wykazano jednak bardzo duże różnice między województwami (odsetek wynosił od 1,4 do 56,0). W grupach CT i CR odsetek dzieci, u których podczas badania stwierdzono obecność laku w przynajmniej jednym zębie szóstym, wyniósł odpowiednio 16,03 i 28,75 , a w zębie siódmym 1,92 i 5,46. Odmienna sytuacja była w grupie P. Odsetek dzieci z zalakowanym przynajmniej jednym zębem szóstym wyniósł 96,83, a siódmym - 92,17, przy czym zalakowane wszystkie cztery zęby szóste stwierdzono u 43,31\% dzieci. Brak laku w zębach szóstych u 3,17\%, a w siódmych u 7,83\% dzieci z grupy P należy tłumaczyć niezgłoszeniem się uczniów do lakowania zębów w gabinecie profilaktyki w okresie poprzedzającym badanie, z którego pochodzą dane przedstawiane w pracy.

Uwzględniając doniesienia ujęte $\mathrm{w}$ polskim i zagranicznym piśmiennictwie, które udowadniają i jednocześnie potwierdzają pozytywny wpływ profilaktycznego lakowania na zdrowie zębów, należy zwrócić uwagę na wyniki: Wędrychowicz-Welman i Stopy [14] - 3-letni program profilaktyczny, w tym lakowanie zębów, obniżył przyrost próchnicy w grupie 11-12-latków; Hilt [22] - po 5 latach obserwacji od lakowania utrzymano lak w 54,1\% pierwszych zębów trzonowych; Vrbica [23] - po 3 latach od zabiegu uszczelniania aż 95,8\% powierzchni zębowych nadal było całkowicie pokrytych lakiem; Schulte i wsp. [24] - dzięki lakowaniu zębów obniżono intensywność próchnicy w grupach dzieci 12-letnich z Heidelbergu i Montpellier; Siudmak [11] - u 12-latków z Dortmundu, nieobjętych lakowaniem zębów, występowało 3-krotnie większe prawdopodobieństwo zachorowania na próchnicę niż u ich rówieśników z grupy profilaktycznej.

\section{WNIOSKI}

Wskaźniki częstości i intensywności próchnicy u 12-latków wskazują na dużą efektywność Programu profilaktycznego. U 12-latków ze wsi obserwuje się większe potrzeby profilaktyczno-lecznicze dla zębów stałych, zwłaszcza I i II zębów trzonowych stałych, niż u ich rówieśników z miasta. Ogólnokrajowe programy profilaktyczno-lecznicze w Polsce, zarówno te wcześniejsze, jak i obecne, sa niewystarczające dla zapewnienia zdrowia jamy ustnej. Korzystne dla stanu zdrowia Polaków byłoby utworzenie programu profilaktyki stomatologicznej o charakterze narodowym, który zapewniłby wszystkim dzieciom niezależnie od miejsca zamieszkania: edukację zdrowotna, rzeczywisty dostęp do świadczeń stomatologicznych od najmłodszych lat, gwarantowane uzupełnianie laku w zębach szóstych po 8 r.ż. oraz profilaktyczne lakowanie zębów siódmych 
oral health indicators are far from reaching the values set out in the WHO guidelines. do 13 r.ż. Wymienione w Programie działania edukacyjno-profilaktyczne mogłyby przynieść korzyści również w tych krajach, gdzie wskaźniki stanu zdrowia jamy ustnej są dalekie od wartości przedstawionych w wytycznych WHO.

\section{Author's contribution}

Study design - U. Kalińska, M. Hartman-Petrycka, B. Błońska-Fajfrowska

Data collection - U. Kalińska

Data interpretation - U. Kalińska, M. Hartman-Petrycka, B. Błońska-Fajfrowska

Statistical analysis - M. Hartman-Petrycka

Manuscript preparation - U. Kalińska, M. Hartman-Petrycka, B. Błońska-Fajfrowska

Literature research - U. Kalińska

\section{REFERENCES}

1. Szatko F. Polski model opieki dentystycznej. Pozytywy i negatywy. Gazeta Lek. 2008; 10: 11-12.

2. Edelstein B.L. The Dental Caries Pandemic and Disparities Problem. BMC Oral Health 2006; 6 Suppl. 1: S2.

3. Scottish Dental Clinical Effectiveness Programme Prevention and Management of Dental Caries in Children. Dental Clinical Guidance. Part V. Referra for Care. Recall. Providing Additional Support. Research, Audit and Service Development. J. Stoma. 2012; 65(5): 755-775.

4. Minister of Health: Dz. U. 2013 Item. 1462. Polish Journal of Laws. Item 1462. Regulation of the Minister of Health of 6 November 2013. Warsaw 2013 5. Minister of Health: DZ. U. 2015. Item 1262. Polish Journal of Laws Item 1262. Regulation of the Minister of Health of 19 August 2015. Warsaw 2015.

6. Bratthall D. Introducing the Significant Caries Index together with a proposa for a new global oral health goal for 12-year-olds. Int. Dent. J. 2000; 50(6) 378-384.

7. Knychalska-Karwan Z. Collection of dental indicators and some tests and classification. Wyd. Czelej. Lublin 2006.

8. Ministry of Health: National Health Monitoring of the Oral Health and it Condition: Oral health of children 12 years of age and adolescents aged 18 years in 2014 in Poland. Warsaw 2015.

9. Perkowska M., Hilt A., Rybarczyk-Townsend E., Wochna-Sobańska M Trend prevalence of morbidity in first permanent molars in 12-year-old children in the Łódź Voivodeship in the years 1978-2008. Nowa Stom. 2010; $47-53$.

10. Chłapowska J. A report, financed by the city of Poznań, on the implementation of the Caries Prevention Programme for children who in the school yea 2009/2010 attended the first and sixth grades of primary schools. Poznań 2010 11. Siudmak B. Retrospective analysis of the effectiveness of fissure sealing in first and second permanent molars of children and teenagers seen within an individual prevention program at the author's dental office in Dortmund between 1998 and 2007. Ann. Acad. Med. Stetin. 2010; 56(2): 58-69.

12. Składnik-Jankowska J., Kaczmarek U. A significant caries index for 12-year-old children from different environments in Lower Silesia. J. Stoma. 2010; 63: 166-173.

13. Rojek R., Stachowiak-Ruda J., Mikołajczyk J., Wieczkowska I., Jarząbek A., Gońda-Domin M., Węsierska K. Dental health practices versus oral health condition in 12-year-old children from West Pomerania Province. J. Stoma. 2017; 70(3): 272-280, doi: 10.5604/01.3001.0010.5020.

14. Wędrychowicz-Welman A., Stopa J. An assessment of the impact of a three-year preventive and treatment programme on oral health in school children. J. Stoma. 2009; 62: 637-648.

15. Nuca C., Amariei C., Borutta A., Petcu L. Prevalence and severity of dental caries in 6- and 12-year-old children in Constanta District (Urban Area), Romania. OHDMBSC 2009; 8(3): 19-24.

16. National Health Program 2007-2015: Attachment to Resolution No. 90/2007 of the Council of Ministers of 15 May 2007. Warsaw 2007.

17. Bratthall D. Estimation of global DMFT for 12 -year-olds in 2004. Int. Dent. J. $2005 ; 55(6): 370-372$.

18. Ministry of Health: National Health Monitoring of the Oral Health and its Condi18. tion: Oral health and preventive and therapeutic needs of children aged 12 in Poland. Warsaw 2013

19. Oral Health Database [online] https://www.mah.se/CAPP/Methods-and-Indices/for-Measurement-of-dental-diseases/Significant-Caries-Index/Significant-Caries-Index-selected-countries/EURO/EURO-G---L/ [Accessed September 9,2019$]$.

20. Gooch B.F., Griffin S.O., Gray S.K., Kohn W.G., Rozier R.G., Siegal M., Fontana M., Brunson D., Carter N., Curtis D.K., Donly K.J. et al. Preventing dental caries through school-based sealant programs: updated recommendations and reviews of evidence. JADA 2009; 140(11): 1356-1365.

21. Irish Oral Health Services Guideline Initiative. Pit and fissure sealants: evidence-based guidance on the use of sealants for the prevention and management of pit and fissure caries. Cork (Ireland): Oral Health Services Research Centre 2010; 49 p.

22. Hilt A. A five-year evaluation of the effectiveness of the programme of preventive sealing of the permanent first molar teeth in Łódź. Prz. Stomatol. Wieku Rozw. 2001; 3/4: 103-108.

23. Vrbic V. Reasons for the caries decline in Slovenia. Community Dent. Oral Epidemiol. 2000; 28(2): 126-132.

24. Schulte A., Rossbach R., Tramini P. Association of caries experience in 12-year-old children in Heidelberg, Germany, and Montpellier, France, with different caries preventive measures. Community Dent. Oral Epidemiol. 2001; 29(5): 354-361. 